\title{
Cellular composition of the sheep corpus luteum in the mid- and late luteal phases of the oestrous cycle
}

\author{
J. D. O'Shea, R. J. Rodgers and P. J. Wright* \\ Departments of Veterinary Preclinical and ${ }^{*}$ Clinical Sciences, University of Melbourne, Parkville, \\ Victoria 3052, Australia
}

\begin{abstract}
Summary. Corpora lutea (CL) from naturally cycling Corriedale ewes were obtained in the mid- and late luteal phases of the oestrous cycle (Days 9 and 13; 5 ewes per group). The cellular composition of these CL was compared by ultrastructural morphometry to determine whether there were changes in numbers of large and small luteal cells consistent with differentiation of some small luteal cells to large luteal cells during the last part of the luteal phase.

No differences between Days 9 and 13 were detected in luteal volume, plasma progesterone concentration, or volume density of any component of the luteal tissue. Large luteal cell numbers (mean \pm s.e.m.) were lower per unit volume of luteal tissue on Day 13 than on Day $9\left(14.1 \pm 0.5\right.$ vs $\left.18.4 \pm 1.3 \times 10^{3} / \mathrm{mm}^{3}, P<0.05\right)$. Mean volume of the individual large luteal cells was greater on Day 13 than on Day 9 $\left(19.65 \pm 0.72 v s^{\prime} 15.60 \pm 1.34 \mu \mathrm{m}^{3} \times 10^{3}, P<0.05\right)$. However, there were no significant differences in numbers or volumes of small luteal cells between Days 9 and 13, and total numbers of large luteal cells per CL were not different between these two days.

These results provide no support for the hypothesis that small luteal cells differentiate into large luteal cells during the oestrous cycle of the sheep.
\end{abstract}

\section{Introduction}

There is evidence that granulosa and theca cells from ovulating follicles are incorporated into developing corpora lutea $(\mathrm{CL})$ in sheep. Structural and histochemical observations support the concept that granulosa cells initially give rise to the developing large luteal cells, while the distinctive population of small luteal cells appears to derive from the theca interna (O'Shea, Cran \& Hay, 1980). These two populations of luteal cells have now been shown to differ in many ways other than size: these include ultrastructural morphology (O'Shea et al., 1979), progesterone-secretory response to luteinizing hormone ( $\mathrm{LH}$ ) in vitro (Fitz, Mayan, Sawyer \& Niswender, 1982; Rodgers \& O'Shea, 1982), receptor content for LH and prostaglandins E-2 and F-2 $\alpha$ (Fitz et al., 1982), and ability to synthesize oxytocin (Rodgers, O'Shea, Findlay, Flint \& Sheldrick, 1983).

There are, however, several lines of evidence to suggest that small luteal cells, or cells of thecal origin, may under natural (cow: Alila \& Hansel, 1984) or experimental (ewe: Cran, 1983) conditions differentiate into cells resembling the granulosa-derived large luteal cells. Data based on counting large and small luteal cells, categorized on the basis of cell diameter, after enzymic dispersion of ovine luteal tissue on various days of the oestrous cycle (Fitz, Sawyer \& Niswender, 1981) also appear to support the idea of differentiation of small luteal cells into large luteal cells during the last part of the oestrous cycle. However, this interpretation of the data of Fitz et al. (1981) depends on two unproven assumptions: firstly, that the cell populations isolated by this methodology accurately reflect the relative numbers of the various cell types in the original luteal tissue, and secondly, that the increase in numbers of 'large luteal cells' represents a true cytodifferentiation of small to large luteal cells, and not simply an increase in size of some or all of the 
small luteal cells. If these two assumptions are correct, morphometric study of CL on different days of the oestrous cycle should confirm an increase in large luteal cell numbers, and a compensating decrease in small luteal cells, between the mid-and late stages of the cycle.

We have therefore compared, by ultrastructural morphometry, the cellular composition of two groups of CL obtained during the mid-and late luteal phases of the oestrous cycle.

\section{Materials and Methods}

Animals. Corriedale ewes maintained on pasture supplemented with clover hay were studied at the Veterinary Clinical Centre, Werribee, during a single mating season (April/May). A vasectomized ram fitted with a harness and crayon was included with the flock, and observations for oestrus were made daily. Corpora lutea were collected on Day $9(N=5)$ or Day $13(N=5)$ of the oestrous cycle (Day $0=$ oestrus). The 5 ewes on Day 9 of the cycle were the same group as reported previously in another study undertaken for a different purpose (O'Shea, Rodgers \& Wright, 1984). CL were collected only from ewes that had shown at least 3 previous periods of oestrus during the mating season. Jugular venous blood samples were collected immediately before anaesthesia, and plasma samples for progesterone assay were stored at $-20^{\circ} \mathrm{C}$.

Tissues. Ovaries containing CL, together with their extrinsic blood vessels, were collected immediately after ewes were killed by exsanguination under pentobarbitone anaesthesia. The ovarian artery was promptly cannulated close to the hilus of the ovary, and blood was flushed from the ovarian vessels by perfusion with $5 \mathrm{ml}$ Ringer's balanced salt solution from a hypodermic syringe under gentle manual pressure at room temperature. Then, $10 \mathrm{ml} 3 \%$ glutaraldehyde in $0 \cdot 1 \mathrm{M}$-cacodylate buffer, $\mathrm{pH} 7 \cdot 3$, at $4^{\circ} \mathrm{C}$, was perfused through the ovary in the same manner at $\simeq 1 \mathrm{ml} / \mathrm{min}$. After perfusion, ovaries were stored for up to $2 \mathrm{~h}$ in the same fixative at $4^{\circ} \mathrm{C}$. CL were then dissected from the ovaries and weighed. A complete cross-sectional slice of tissue $\simeq 1 \mathrm{~mm}$ thick was cut from the centre of each CL, in a plane parallel to the surface of the ovary. Each slice was then divided into 4 equal quadrants, and from each quadrant 2 blocks of tissue $\simeq 1 \mathrm{~mm}^{3}$ were taken for electron microscopy, one from the outer part of the quadrant and the other from the inner part. Outer blocks were taken from tissue about one third of the way from the capsule of the CL to its centre, and inner blocks from tissue about two thirds of this distance. To represent the outer and inner regions of the luteal tissue in their proper proportions, all 4 blocks from the outer part, but only 1 randomly selected inner block, were used for morphometry. These blocks were then placed in $3 \%$ glutaraldehyde for $1 \mathrm{~h}$ at $4^{\circ} \mathrm{C}$, rinsed in cacodylate buffer, and post-fixed in $1 \%$ osmium tetroxide in distilled water for $2 \mathrm{~h}$ at room temperature. Blocks were stained for $30 \mathrm{~min}$ in $0.5 \%$ aqueous uranyl acetate, dehydrated in alcohol and embedded in araldite (Durcupan: Fluka, Buchs, Switzerland). Thin sections were stained with uranyl acetate and lead citrate, and examined in a Philips EM 300 electron microscope. For each block, 5 randomly selected complete grid squares of a 200-mesh grid were photographed at a magnification of $\times 1000$. Prints for morphometric examination were produced at a final maginification of $\times 2280$.

The specific gravity of the tissue of each CL was determined using a flotation method in solutions of copper sulphate of known specific gravity (Long, King \& Sperry, 1968). Volume was then calculated by dividing luteal weight by specific gravity. The volume of any central cavity in CL was calculated from 2 measured diameters of the cavity at $90^{\circ}$ to one another, and subtracted from the volume as calculated above.

Morphometric methods. Methods used for measurement of volume density, cell number and cell volume have been reported in detail elsewhere (Rodgers, O'Shea \& Bruce, 1984), and are summarized only briefly here.

Volume density was determined by the point-counting method (Weibel, 1979), using a 21-bar, 42-point (M42) grid, of $\simeq 131.3 \mathrm{~cm}^{2}$, reproduced as a transparent sheet and dropped once onto 
each micrograph. Thus 42 points were counted for each micrograph, 5 micrographs from each block, 5 blocks from each animal and 5 animals per group, a total of 5250 points per group. Volume density of each component of the tissue, as a percentage, was calculated from the number of 'hits' on that component, divided by the total number of hits and multiplied by 100 .

Cell numbers per unit volume of fixed tissue $\left(\mathrm{N}_{\mathrm{v}}\right)$ were calculated using the formula

$$
N_{v}=\frac{1}{\beta} \times \frac{N_{A}^{1 \cdot 5}}{V_{V}^{0 \cdot 5}} \quad \text { (Formula 2.83: Weibel, 1979) }
$$

where $\beta$ is a correction factor based on nuclear shape, $N_{A}$ is the number of nuclei of each type per unit area of micrograph, and $V_{V}$ is the volume fraction of nuclei (the combined area of all nuclei of a particular type divided by the area of the electron micrographs). Nuclei of large and small luteal cells, and other cell types, were given a value of 1.382 for $\beta$. Endothelial cells and pericytes were given a value of 1.9 , and fibrocytes a value of 1.7 (Rodgers et al., 1984). The areas of electron micrographs, and of individual nuclei, were measured using an image analyser (Videoplan: Carl Zeiss, Obercochen, West Germany). Correction of these values for shrinkage was based on the use of a linear shrinkage factor (Rodgers et al., 1984). Total cell numbers per CL were the product of cell numbers per unit volume and the volume of the CL. The mean volume of each cell type was calculated by dividing volume density $(\%)$ by the number of cells per unit volume of tissue. Cell diameters of large and small luteal cells were calculated from volume, assuming the cells to be spheres (volume $=4 / 3 \pi r^{3}$ ).

Progesterone assay. Plasma progesterone concentrations were determined by the radioimmunoassay described by Hossain, Lee, Clarke \& O'Shea (1979). All samples were measured in the same assay. The within-assay coefficient of variation of this essay was $<20 \%$ between 0.08 and $7.05 \mathrm{ng} / \mathrm{ml}$, calculated by the methods and computer programme of Burger, Lee \& Rennie (1972), and all samples fell within that range.

Statistical analysis. Data were analysed by Student's $t$ test, using arcsine transformation for percentage values. All values are reported as mean \pm s.e.m.

\section{Results}

Mean volume of the $\mathrm{CL}$ from ewes on Day $13\left(550 \pm 38 \mathrm{~mm}^{3}\right)$ was not different $(P>0.05)$ from that on Day $9\left(520 \pm 34 \mathrm{~mm}^{3}\right)$. Nor was there any significant difference in plasma progesterone concentrations between the two groups (Day $9=4.34 \pm 0.32 \mathrm{ng} / \mathrm{ml}$; Day $13=3.31 \pm 0.46 \mathrm{ng} / \mathrm{ml})$.

Table 1. Numbers of nuclei of different cell types counted in sheep luteal tissues on Days 9 and 13 of the oestrous cycle (5 CL on each day)

\begin{tabular}{lcc}
\hline \multirow{2}{*}{\multicolumn{1}{c}{ Cell type }} & \multicolumn{2}{c}{ Number of nuclei counted } \\
\cline { 2 - 3 } \multicolumn{1}{c}{ Day 9} & Day 13 \\
\hline Endothelial cells and pericytes & 1747 & 1851 \\
Large luteal cells & 232 & 168 \\
Small luteal cells & 942 & 714 \\
Fibrocytes & 340 & 295 \\
Other cell types or unidentified & 287 & 287 \\
Total & 3548 & 3315 \\
\hline
\end{tabular}


No mitotic figures were seen among 3315 nuclei examined in electron micrographs from CL on Day 13, and only one mitotic figure was observed amongst 3548 nuclei from Day 9 (see Table I for classification of these cells by cell type). The sole mitotic figure was in a fibrocyte, giving a mitotic index of $0.29 \%$ in this cell type. No dead cells were observed on Day 9. Amongst the CL from Day 13 , dead cells were seen in only two. One of these contained 3 dead cells, whose identity could not be established, within the substance of the luteal tissue (Fig. 1). The other contained one dead cell

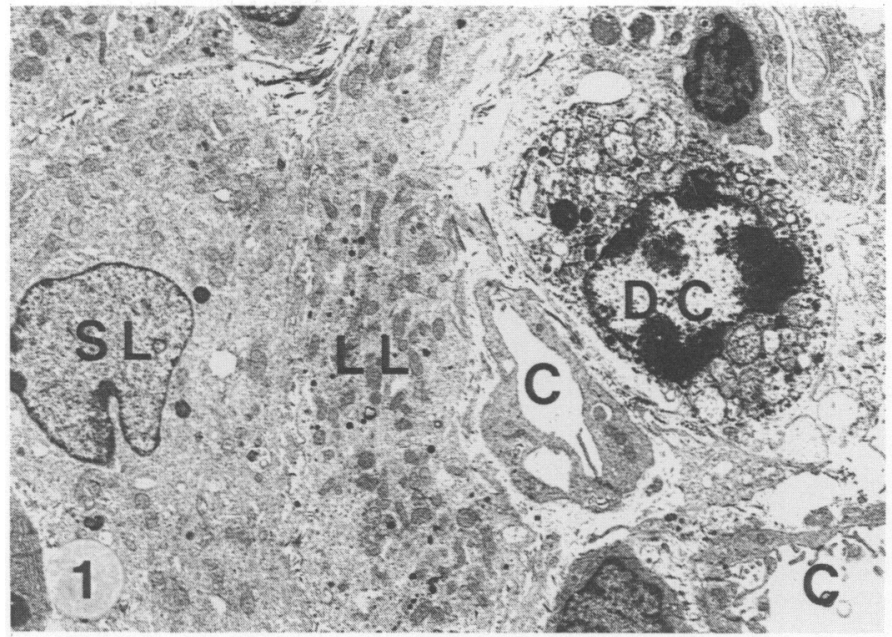

Fig. 1. Example of a dead cell (DC) in luteal tissue on Day 13 of the oestrous cycle. Condensation and margination of nuclear chromatin are evident, and cytoplasmic organelles are swollen and distended. Parts of a small luteal (SL) and a large luteal (LL) cell are present, and two capillaries $(\mathrm{C})$ are seen. $\times 3500$.

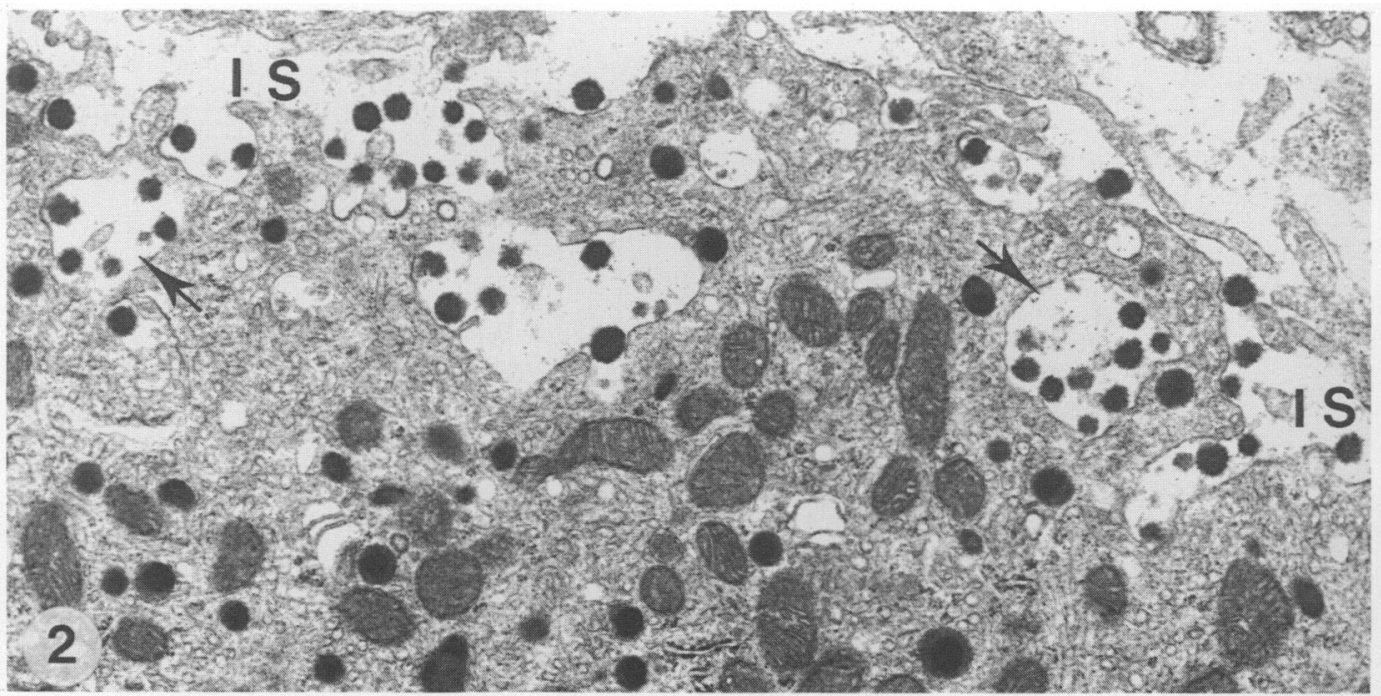

Fig. 2. Edge of a large luteal cell on Day 13 of the oestrous cycle, showing the accumulation of dense secretory granules in large membrane-bound compartments close to the cell surface (arrows), and release of large numbers of granules into the intercellular space (IS). $\times 21500$. 
Table 2. Volume density (\%) of the cellular and non-cellular components of sheep luteal tissue on Days 9 and 13 of the oestrous cycle

\begin{tabular}{lrr}
\hline & \multicolumn{2}{c}{ Days of oestrous cycle } \\
\cline { 2 - 3 } Component of luteal tissue & \multicolumn{1}{c}{9} & \multicolumn{1}{c}{13} \\
\hline Endothelial cells and pericytes & $12 \cdot 8 \pm 1 \cdot 1$ & $12 \cdot 8 \pm 0 \cdot 9$ \\
Large luteal cells & $28 \cdot 3 \pm 2 \cdot 1$ & $27 \cdot 6 \pm 1 \cdot 0$ \\
Small luteal cells & $22 \cdot 2 \pm 1 \cdot 4$ & $21 \cdot 9 \pm 2 \cdot 3$ \\
Fibrocytes & $5 \cdot 6 \pm 1 \cdot 3$ & $6 \cdot 1 \pm 1 \cdot 4$ \\
Other cell types or unidentified & $3 \cdot 2 \pm 0 \cdot 5$ & $3 \cdot 5 \pm 0 \cdot 8$ \\
Vessel lumen & $12 \cdot 2 \pm 1 \cdot 1$ & $11 \cdot 2 \pm 1 \cdot 1$ \\
Intercellular space & $15 \cdot 7 \pm 3 \cdot 1$ & $16 \cdot 9 \pm 1 \cdot 3$ \\
\hline
\end{tabular}

Values are mean \pm s.e.m. for $5 \mathrm{CL} /$ group.

Table 3. Number of cells per unit volume of tissue, and per CL, in luteal tissue from sheep on Days 9 and 13 of the oestrous cycle

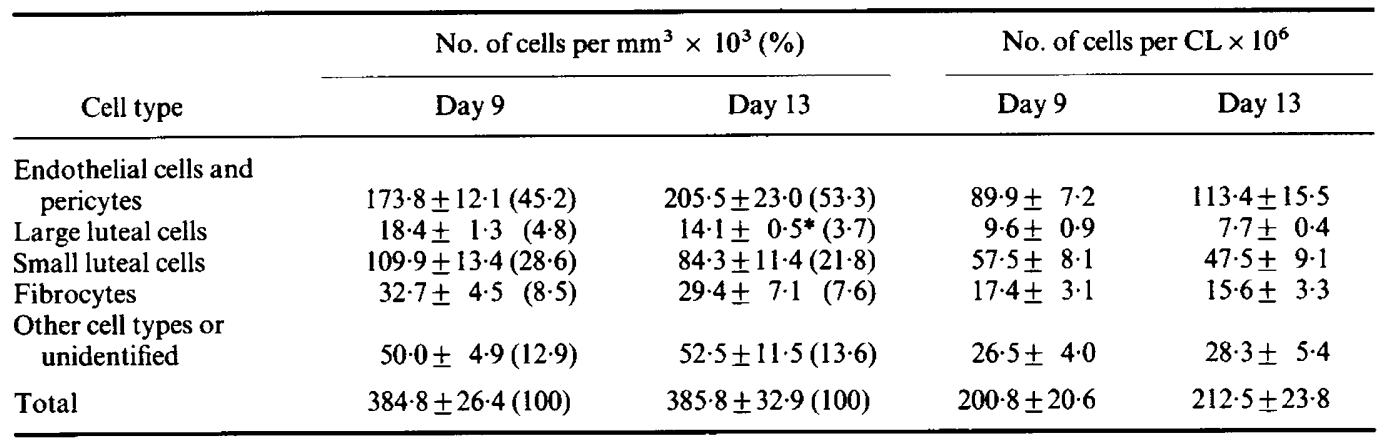

Values are mean \pm s.e.m. for $5 \mathrm{CL} /$ group.

${ }^{*} P<0.05$ ( $t$ test) compared with Day 9 .

Table 4. Volume of each of the four major cell types in luteal tissue from sheep on Days 9 and 13 of the oestrous cycle

\begin{tabular}{lcc}
\hline \multirow{1}{*}{\multicolumn{1}{c}{ Cell type }} & \multicolumn{2}{c}{ Cell volume $\left(\mu \mathrm{m}^{3} \times 10^{-3}\right)$} \\
\cline { 2 - 3 } \multicolumn{1}{c}{ Day 9} & Day 13 \\
\hline Endothelial cells and pericytes & $0 \cdot 75 \pm 0.08$ & $0.64 \pm 0.06$ \\
Large luteal cells & $15 \cdot 60 \pm 1.34$ & $19.65 \pm 0.72^{*}$ \\
Small luteal cells & $2 \cdot 12 \pm 0 \cdot 26$ & $2 \cdot 72 \pm 0.31$ \\
Fibrocytes & $1.69 \pm 0.32$ & $2 \cdot 18 \pm 0 \cdot 22$ \\
\hline
\end{tabular}

Values are mean \pm s.e.m. for $5 \mathrm{CL}$ /group.

${ }^{*} P<0.05$ ( $t$ test) compared with Day 9 .

within a blood capillary, cells in this position not being counted for morphometric purposes. However, dead cells within capillaries are a feature of luteal regression in sheep (O'Shea, Nightingale \& Chamley, 1977), and this CL came from the ewe with the lowest plasma progesterone concentration $(1 \cdot 70 \mathrm{ng} / \mathrm{ml})$ of any in either group. Secretory granules (Gemmell, Stacy \& Thorburn, 1974; Paavola \& Christensen, 1981) in the cytoplasm of the large luteal cells were also very sparse in this CL, 
another correlate of the onset of luteal regression (Gemmell et al., 1974). Secretory granules were numerous in the large luteal cells from all other CL of both groups, and were generally distributed singly throughout the cytoplasm, with evidence of release of the contents of some granules into the intercellular space. However, in one CL from each group a small proportion of the large luteal cells showed clustering of granules into large membrane-bound compartments close to the plasma membrane, with associated release of their contents en masse (Fig. 2).

No differences were observed between CL from Days 9 and 13 in terms of volume density of any tissue component (Table 2). Total numbers of cells of all types were closely similar in the two groups, in terms both of cells per unit volume and cells per CL (Table 3). Amongst the individual cell types, the only significant difference detected was in relation to large luteal cells per unit volume of luteal tissue: these cells were less numerous in the CL on Day 13. Although mean numbers of large luteal cells per CL were somewhat lower on Day 13, this difference did not attain significance. The ratio of large to small luteal cells, at $\simeq 1: 6$, was almost identical on the two days of the oestrous cycle studied, in terms both of numbers of cells per unit volume and numbers per CL. A difference in cell volume between Days 9 and 13 was observed only amongst large luteal cells, which were larger on Day 13 (Table 4). This difference in size compensated for the smaller numbers of these cells in maintaining volume density of the large luteal cells closely similar in the two groups (Table 2).

\section{Discussion}

The major conclusion from this study is that no evidence was found to support the concept that small luteal cells differentiate into large luteal cells during the last part of the life-span of cyclic corpora lutea in the sheep. If anything, the numbers of both of these cell types declined between Days 9 and 13 of the cycle (representing about 8 and 12 days after ovulation), although this trend was significant only for the large luteal cells, and only on a per-unit volume of luteal tissue basis. However, the categorization of cells into large or small luteal cells in this study was based on ultrastructural cytology as defined by O'Shea et al. (1979), whereas that by Fitz et al. (1981), suggesting a transformation between the cell types, was based on cell size. The two sets of data are therefore not necessarily inconsistent, because it is possible that the enlargement of some small luteal cells late in the cycle might be sufficient to allow them to be categorized as large luteal cells on the basis of size. In the present study, the mean volume per luteal cell was greater on Day 13 for both types of luteal cell, although significantly greater only for the large luteal cells. Cell diameters calculated from the mean volumes shown in Table 4, if the cells were regarded as spheres, were as follows: large luteal cells 31.0 and $33.5 \mu \mathrm{m}$, and small luteal cells 16.0 and $17.4 \mu \mathrm{m}$ on Days 9 and 13 respectively. On this basis the mean diameter of $17.4 \mu \mathrm{m}$ calculated for small luteal cells on Day 13 was clearly below the lower limit of $22 \mu \mathrm{m}$ used by Fitz et al. (1981) to define dissociated large luteal cells. However, it remains possible that some individual members of this ultrastructurally-defined cell population could have been large enough to be included amongst the large luteal cells counted by Fitz et al. (1981).

An extension of the concept that small luteal cells differentiate into large luteal cells has been proposed by Niswender, Schwall, Fitz, Farin \& Sawyer (1985) who considered a model in which the CL contains a population of mitotically-active stem cells (unidentified in morphological terms but presumably of small size) which differentiate into small steroidogenic luteal cells which in turn develop into large luteal cells. This model further requires that either large luteal cells continue to increase in numbers as long as differentiation continues, or pre-existing large luteal cells degenerate and disappear to be replaced by newly formed cells. Clearly the present results provide no support for the former requirement, and cell death amongst large luteal cells has not been demonstrated in this or other studies of the sheep CL until the onset of luteal regression. Nor was mitosis observed to any significant extent in any population of cells at Day 9 or Day 13, although mitosis is certainly a feature of younger CL (McClellan, Diekman, Abel \& Niswender, 1975; O'Shea et al., 1980). 
On balance, it seems unnecessary on the basis of present data to postulate any additional source of large luteal cells in sheep other than the granulosa cells of ovulating follicles, provided that large luteal cells are not identified solely on the basis of arbitrarily-defined size limits. The granulosa cells of preovulatory follicles of sheep occur in numbers similar to those estimated here for large luteal cells, with a mean \pm s.e.m. value of $7.68 \pm 0.53 \times 10^{6}$ as measured by morphometry (O'Shea, Wright \& Davis, 1985). Therefore, with little if any post-ovulatory mitosis, provided that there is no substantial amount of large luteal cell death, the granulosa cells could be the sole source of the morphologically and functionally distinct population of large luteal cells which can be recognized throughout the normal oestrous cycle and pregnancy (O'Shea et al., 1979; O'Shea \& Wright, 1985). Data showing that, under experimental conditions, as in luteinization of follicular cysts induced by PMSG administration (Cran, 1983) or after the administration of hCG in vivo (Niswender et al., 1985), there may be hypertrophy of theca-derived or small luteal cells are not necessarily incompatible with the concept that large luteal cells are normally derived solely from granulosa cells.

We thank Mrs Anne Bartlett, Mr Phillip Smith and Mr Ken Snibson for excellent technical assistance; Dr R. I. Cox for the antiserum to progesterone; and Professor G. C. Ryan for access to the image analyser. Financial support was provided by the Australian Meat Research Committee.

\section{References}

Alila, H.W. \& Hansel, W. (1984) Origin of different cell types in the bovine corpus luteum as characterized by specific monoclonal antibodies. Biol. Reprod. 31, 1015-1025.

Burger, H.G., Lee, V.W.K. \& Rennie, G.C. (1972) A generalized computer programme for the treatment of data from competitive protein binding assays including radioimmunoassays. J. Lab. clin. Med. 80, $302-312$.

Cran, D.G. (1983) Follicular development in the sheep after priming with PMSG. J. Reprod. Fert. 67, $415-423$.

Fitz, T.A., Sawyer, H.R. \& Niswender, G.D. (1981) Characterization of two steroidogenic cell types in the ovine corpus luteum. Biol. Reprod. 24, Suppl. 1, 54, Abstr.

Fitz, T.A., Mayan, M.H., Sawyer, H.R. \& Niswender, G.D. (1982) Characterization of two steroidogenic cell types in the ovine corpus luteum. Biol. Reprod. 27, 703-711.

Gemmell, R.T., Stacy, B.D. \& Thorburn, G.D. (1974) Ultrastructural study of secretory granules in the corpus luteum of the sheep during the oestrous cycle. Biol. Reprod. 11, 447-462.

Hossain, M.I., Lee, C.S., Clarke, I.J. \& O'Shea, J.D. (1979) Ovarian and luteal blood flow, and peripheral plasma progesterone levels, in cyclic guinea-pigs. $J$. Reprod. Fert. 57, 167-174.

Long, C., King, E.J. \& Sperry, W.M. (1968) In Biochemists' Handbook, pp. 1070-1072. E. \& F. N. Spon Ltd, London.

McClellan, M.C., Diekman, M.A., Abel, J.H. \& Niswender, G.D. (1975) Luteinizing hormone, progesterone and the morphological development of normal and superovulated corpora lutea in sheep. Cell Tiss. Res. 164, 291-307.

Niswender, D.G., Schwall, R.H., Fitz, T.A., Farin, C. \& Sawyer, H.R. (1985) Regulation of luteal function in domestic ruminants: new concepts. Recent Prog. Horm. Res. 41, 101-151.
O'Shea, J.D. \& Wright, P.J. (1985) Regression of the corpus luteum of pregnancy following parturition in the ewe. Acta anat. 122, 69-76.

O'Shea, J.D., Nightingale, M.G. \& Chamley, W.A. (1977) Changes in small blood vessels during cyclical luteal regression in sheep. Biol. Reprod. 17, 162-177.

O'Shea, J.D., Cran, D.G. \& Hay, M.F. (1979) The small luteal cell of the sheep. J. Anat. 128, 239-251.

O'Shea, J.D., Cran, D.G. \& Hay, M.F. (1980) Fate of the theca interna following ovulation in the ewe. Cell Tiss. Res. 210, 305-319.

O'Shea, J.D., Rodgers, R.J. \& Wright, P.J. (1984) Morphometric analysis and function in vivo and in vitro of corpora lutea from ewes treated with LHRH during seasonal anoestrus. J. Reprod. Fert. 72, 75-85.

O'Shea, J.D., Wright, P.J. \& Davis, K.E. (1985) Numbers of granulosa cells in preovulatory follicles from ewes during the breeding season and after LHRH administration during seasonal anoestrus. Proc. $X I I$ Int. Anat. Congr., London, 529, Abstr.

Paavola, L.G. \& Christensen, A.K. (1981) Characterization of granule types in luteal cells of sheep at the time of maximum progesterone secretion. Biol. Reprod. 25, 203-215.

Rodgers, R.J. \& O'Shea, J.D. (1982) Purification, morphology, and progesterone production and content of three cell types isolated from the corpus luteum of the sheep. Aust. J. biol. Sci. 35, 441-455.

Rodgers, R.J., O'Shea, J.D., Findlay, J.K., Flint, A.P.F. \& Sheldrick, E.L. (1983) Large luteal cells the source of luteal oxytocin in the sheep. Endocrinology 113, 2302-2304.

Rodgers, R.J., O'Shea, J.D. \& Bruce, N.W. (1984) Morphometric analysis of the cellular composition of the ovine corpus luteum. J. Anat. 138, 757-769.

Weibel, F.R. (1979) Stereological Methods, vol. 1. Practical Methods for Biological Morphometry. Academic Press, London. 